\title{
The Implementation Of Teacher Internship Program Ii To Undergraduate English Students' Competency Mastery
}

\author{
Teti Ratnawulan, Hilman Farouq Ghoer, Dadang Suherman, Wachyudin \\ \{teti.ratnawulans@gmail.com¹, ghoer23@yahoo.com², dadangsuherman1811@yahoo.com ${ }^{3}$, \\ wachyudoji22@gmail.com $\left.{ }^{4}\right\}$ \\ Special Education Program, FKIP- Universitas Islam Nusantara, Bandung, Indonesia ${ }^{1,3}$, Arabic \\ Education Program, FKIP- Universitas Islam Nusantara, Bandung, Indonesia ${ }^{2}$, Indonesian Education \\ Program, FKIP- Universitas Islam Nusantara, Bandung, Indonesia ${ }^{4}$
}

\begin{abstract}
In Teacher Internship Program II, the group of students are in charge to observe school culture, the four basic competencies of teachers and its understanding, and the job description of teachers and educative staffs. The applied research method was qualitative. The result of the research showed that the instruments of Teacher Internship Program II has met standard instruments. The instruments only needs to be guided and elaborated in accordance with the needs of each school; as for the obstacles that occur that is the technical implementation having timetable clash, and attitudes in collecting the data, at the opening and closing program requiring supervisors because the atmosphere of each school is not the same, and it must always be evaluated and monitored continuously by supervisors; for the design of Teacher Internship Program II is good enough. It only needs socialization and deepening of the theory. In the way of developing of teachers' attitude, it requires intensive understanding and deepening about eight (8) education standards in order to prepare Teacher Internship Program III (teaching assistance) with soft skills and hard skills (such as communicating using English in listening, speaking, reading and writing aspects).
\end{abstract}

Keywords: teacher competencies; Internship Program II; education standard.

\section{Introduction}

In the Curriculum based competencies of University, it was declared that PPLK program was changed into Internship Program 1, 2, and 3. It was the part of integral in the subject of Education profession, Teacher profession, and Microteaching.

Internship Program is the one of important and influence program for improving the knowledge of university students as a professional teacher in the future.

Teacher of English Department should be able to mastery, comprehend and applied 4 based competence of teacher (Kompetensi Dasar Guru) which there are: competence of pedagogy (kompetensi dasar pedagogic), competence of personality (kompetensi dasar kepribadian), competence of social (kompetensi dasar social) and competence of professional(kompetensi dasar professional), after Internship Program I finished, students should be able to stabilized competence of education academic, related to the subject 
academic and teacher skill to develop learning media. in Internship Program 2, group of students should observe the school environment, improving 4 based competence of teacher and comprehending based competence of teacher and describing a job description of Teacher.

The subjects which supported as a precondition of Internship Program is MKDK subjects, there are education profession, education psychology, introduction of education, curriculum learning. Internship Program 1 is started in the medieval of fourth semester in 2016/2017, which the results were various. It can be reviewed to the students, school, faculty or UPT Internship Program. After Internship Program 1, it is continued to Internship Program 2 and in semester 6 students have Internship Program 3, and guidance book of Internship Program 1 is the outcome which has patent. Depend on first study in PLB, the good result of Internship Program is A and B, but there is a problem that student, school, and faculty and UPT Internship Program, furthermore, it is happened in English department in Internship Program 2 , which prepared under graduated students with relevant soft skills and hard skills and aligned competence of personality, professional, pedagogic and social (students should be able to used English in communication). Bachelor with good personality, competence in English subject, and have motivation to development and challenge in the future, and can be adaptation in their ages.

In other words, in terms of the student evaluation, score of Internship Program in one study program was satisfactory. The final result of Internship Program is obtained from attendance, Internship Program theory and practice. Satisfactory score have not been able to describe that the students have mastery the four basic competencies of prospective teachers and have the knowledge, attitudes, and skills needed in school management and outside school, and collecting, reviewing data relating to standardization of management, standardization of content, standardization of process, standardization of competence, standardization of facilities, standardization of educators and education personnel, and financing standards.

There are various opinions from the school, it has a positive and negative effect for both students and schools.

Theoretically the mastery of basic competencies has a positive effect on students and cooperation with schools for the service of the school community concerned. In other words it was a mutualism. In the reality, there are schools that refuse, feel patronized and other reasons, school programs are already running, and disrupt the learning activities of students in schools and students who are studying in university. Based on the results of the 1st year research, there were recommended that students still have to improve pedagogic, professional, social and personality competencies. The results of the 1st year research are model of Internship Program 1, guidance book of Internship Program 1 adjusted to the study program (PLB) and manual Teaching Book of Internship Program 1.

Does the argument above, students of Internship Program 2 get the above-average score which describes the 4 basic competencies of prospective teachers and become a reliable administrative manager? Are the students comfortable in the school environment of the practice?

So, this literacy study and preliminary study, this research needs to be conducted, it was to find out the mastery of the basic competencies of the teacher candidates of Internship Program 2 in collecting and reviewing related to standardization of management, standardization of content, standardization of process, standardization of competence, standardization of facilities, standardization of educators and education personnel, and financing standards. 
Some of the phenomena described above imply that: Satisfactory value does not reflect the competence of the 4 basic competencies of prospective teachers and school management; there is a problems during Internship Program practice; there is still miss information about Internship Program 2; the problem of 4th semester students in looking for the system of school management. Therefore the problem statement of this research is what is the appropriate design of Internship Program 2 which is to develop in FKIP, Uninus Bandung?

Specifically the questions in this study are formulated as follows:

1. How is the instrument that developed in Internship Program 2?

2. What are factors that make the Internship Program 2 less than optimal?

3. What kind of Internship Program development design which expected by FKIP Uninus Bandung and related institutions?

4. How to build a teacher attitude in this Internship Program?

\section{Literature Review}

\subsection{Definition and competence of Internship Program}

Internship Program 2 Program is an activity to have experience related to school management which includes standardization of management, standardization of content, standardization of process, standardization of competence, standardization of facilities, standardization of educators and education personnel, and financing standards.

Students of Internship Program 2 Program are expected to get ideal school management insights that can be identified, addressed and internalized through various activities both in schools or other educational institutions and the findings in this research field can be used as reflection and sharing in various scientific discussions in lectures guided by a supervisor.

\footnotetext{
Aims

Internship Program 2 aimed to establish educational academic competence and it's related to academic competence in the field of study and strengthen the initial ability of prospective teachers to develop learning media.

\section{Objectives}

1. Establish teachers' personality that has the knowledge, attitudes, and skills which required in School Management as well as Outside Schools;

2. Collect and review data on School Management in related to standardization of management, standardization of content, standardization of process, standardization of competence, standardization of facilities, standardization of educators and education personnel, and financing standards;

3. Strengthening FKIP Uninus partnership with schools / educational institutions.
}

\subsection{Qualification of Academic Professional Teachers}

The term profession is often interpreted as a person's work that is done routinely and a financial income in his life, such as lawyers, doctors, architects, teachers, athletes, traders, torturers, dancers, and others. According to Bennet [1], the main features of a profession are as follows: 
1. An employments' position should has the function and social significance that has determine (crucial)

2. An employments' positions should be required the specific skills.

3. The skills that demanded by the employments' position are obtained through problem solving using scientific theories and methods

4. The employments' position should be based on knowledge, systematic, explicit discipline, which is not just the opinion of the public

5. The employments' position should be required education at the college level with considerable time

6. The process of education in the employments' position is an application and socialization of the values of the professional itself

7. In providing services to the society, members of the profession should keep up to a code of ethics controlled by professional organizations

8. Each member of the profession has the freedom to give judgment to the problems of the profession that faced

9. In practice of serving the public, members of the profession are autonomous and free from interference by outsiders

10. This position has high prestige in the community, and therefore it receives high rewards.

Being a professional teacher requires the promotion of autonomy to maintain its expertise towards professionalism, which may need to be exercised in order to make it valued and appreciated [2].

\section{School management}

The school management should be contained standardization of management, standardization of content, standardization of process, standardization of competence, standardization of facilities, standardization of educators and education personnel, financing standards and Assessment Standards based on PP No. 19 of 2005. The school management should be collected and assessed to personality of teachers' candidate who has the knowledge, attitudes and skills in the implementation of Internship Program 2, it is applied for mastery the competencies of the candidates for the English Language Teachers of FKIP Uninus and other Study Programs at FKIP Uninus.

\section{Research Method}

This qualitative research used analytic descriptive method. Descriptive research mostly done in social science especially behavioral science [3, p. 75]. According to Furqon \& Emilia [4, p. 45], the most commonly used data collection techniques consist of three kinds: observation, interview and document analysis.

In accordance to the type of data, the instrument of this study used a study documentation of the results of learning outcomes. While the non-test instrument consists of report on the Internship Program 2, questionnaire. In this study the questionnaire is used to measure and know the student's response to the mastery of the implementation of Internship Program 2 program. and the list of entries is given to the students, after completion of the lesson, in order to know opinions or responses students about mastery of the implementation of Internship Program 2 program and obstacles in implementing Internship Program 2 program. 
This pattern will be used as the basis for formulating the conceptual design of Internship Program 2, hopefully the formulation can be used as a Design in other courses as the implementation of Universities' Curriculum (KBK berbasis KKNI).

The results of the study can be useful for materials to provide explanations or explanatory for curriculum evaluation, performance evaluation of supervisors and other reference materials for the Fakultas Keguruan dan Ilmu pendidikan Uninus and other LPTK, education authorities and partner schools in Bandung.

The usability of the research results are as follows:

1. For the development of Internship Program 2 theory.

2. Contribution to improvement of practice. This qualitative research describes and analyzes the important events, and the processes.

3. Contributions to policy determination. The results of qualitative research can contribute to the formulation, implementation and change of policies.

4. Contribution to clarification of social issues and actions

5. Contribution for case studies, which cannot be examined by ordinary research.

The data Sources in this study are the leader of UPT PPLK and Internship Program, Staff of UPT PPLK and Internship Program, Lecturers of Internship Program 2, Supervisors of Internship Program 2, and Pendidikan Luar Biasa (PLB). (Limited scale test as first year of study), limited testing in Internship Program 2 (second year) in English Study Program, Implementation of Internship Program 3 for wide scale test (Third year) and internship validation test 1,2, and 3 on other study programs on fourth year 4 . All data sources have the same value, and become the main data source.

Based on a preliminary study on 8 Study Programs at FKIP Uninus Bandung, English Language Study Program was established which was located on Jalan Sukarno-Hatta No. 530 Bandung, with partner schools of SMA Mekar Arum, MAN 2, SMA PGRI 2, SMA Istiqomah, SMA 21, SMKN 6, SMK 10, SMA Dayeuh Kolot, SMAN 12, and SMA Sirnamiskin.

\section{Finding And Discussion}

Based on research on 10 schools and lecturers and the results of interviews with students, according to the theory of Internship Program 2 contains 8 educational standards namely school management which includes management standards management, content standards, process standards, graduate competency standards, standards of educators and education personnel, standards financing, standard facilities and assessment standards [5].

Based on the research question about the instrument of Internship Program 2 has been fulfilled the standard instrument; the second research question about the problem that occur in the technical implementation of the clash with the lectures, manners in the data retrieval

It can be described that Students lack of discipline; There is no clear schedule for achieving the points that should be achieved; Less guidance / control; Instrument achievement forms (achievement steps) are not available; For the teacher as a guidance teacher, they did not know about 8 standards; Almost nothing, the practitioner just adapt to the class that will be observed and the schedule of activities in the school; Still miss communication for coming to school, so the tutor teachers should reprove repeatedly; Meeting time with tutor teachers and students; Mastery of internship theory is still lacking; students' meeting time with tutor teachers was clashing, but it can be solved. 
According to the supervisor: there is still an assumption that students should teach in class and being a teacher pickets so that they are not in appropriate with the readiness of students in Internship Program 2; there are still difficulty in arranging schedule of Internship Program 2 practices; school documents and documentation of school funding are not completed as required by students.

In the third question, the design / guide of Internship Program 2 is expected have a good format for students' guidance, a format should be filled by the school after the practitioner observes; simple; but the design is better, the suitability of the Internship Program 2 schedule with the program in the school should be considered so that the implementation will be as expected; need to simplify questions, so that they are more understand; Schedule for submission, preparation of Internship Program 2 materials, 8 standard material preparation, guidance book (attendance list, content / material and signature) are required; It needs 8 standardization of observations and followed by making RPP so that when Internship Program 3 , students have understood.

According to the lecturer: it is expected that it can direct students in Internship Program 2 class and Internship Program activities in the field, to strengthen educational academic competence and its relation to academic competence in the field of study and establish learning media.

In the fourth question is how to build a teacher attitude in Internship Program 2 program: Students should be a discipline in the task; responsible; manners in appearance; attitude and behavior; just interview directly with the management team; guidance on the attitude and language usage; There needs a supervisor with a time frequency and handed back to Uninus; should prioritize the formation of character, confidence, responsibility and discipline; The report is examined by the supervisor, the timing should be clear, the contents of the report should be similar in the condition of the school in a professional manner, opening and closing accompanied by a supervisor.

Students need to deepen or master the personal and social competence. According to the lecturers: to gain experience in 8 educational standards, whereas according to the students that to make Internship Program 2 instrument need to be guided and described depend on school necessary, there are problems that found in the opening and closing time should be accompanied by supervisor because the atmosphere of each school is not similar, and it always be evaluated and monitored continuously by the supervisor; for design of Internship Program 2 , it is good enough to only need socialization and deepening of Internship Program 2 theory.

For questions about how to build teacher attitudes in Internship Program 2 is needed to an intensive understanding and deepening of the 8 education standards and it can be used to prepare for faced Internship Program 3 (teaching assistance).

In the English course for Internship Program 2, preparing graduates with relevant soft skills and hard skills in aligned with personal, professional, pedagogic and social skills (including being able to communicate in English in both listening, speaking, reading and writing). To create graduates who are faithful and noble, Master of Science in English, and sensitive to the demands of future changes and challenges, and have a high ability of adaptability to his era.

The final result of the Internship Program is obtained from attendance, Internship Program theory, and Internship Program practice. The students' evaluation of Internship Program courses from several study programs the results were satisfactory. Satisfactory score has not been able to describe the mastery of the four basic competencies of prospective teachers and possess the knowledge, attitudes, and skills required in school management as well as outside the school, including collecting, reviewing data relating to standardization of 
management, standardization of content, standardization of process, standardization of competence, standardization of facilities, standardization of educators and education personnel, financing standards. The reality in the field there are schools that reject, feel patronized and other reasons, school programs are running, as well as interfere with student learning activities in schools and college students. Based on the results of the 2nd year research on Internship Program 2, it is recommended that students still have to improve pedagogic, professional, social and personality competencies and need to be followed by competency control in the Internship Program 2 of school management. The result of the 2 nd year research is the apprentice model 2, the apprentice 2 is tailored to the course of study (English Education) and Internship Book 2.

\section{Conclusion}

The instrument of teacher internships program II has fulfilled instruments standard, it should be guided and elaborated in accordance with the needs of each school; as for the obstacles that occur in the implementation of clashing with the time of lecture, and the good way in taking data, at the opening and closing is needed the lecturer to guide the students because each school has different atmosphere, and it must always be evaluated and monitored by the supervisor; for internship program II, the design is good enough but it needs socialization and deepening of the theory of internship program II.

Teacher Internship Program II has met standard instruments. The instruments only need to be guided and elaborated in accordance with the needs of each school; as for the obstacles that occur that is the technical implementation having timetable clash, and attitudes in collecting the data, at the opening and closing program requiring supervisors because the atmosphere of each school is not the same, and it must always be evaluated and monitored continuously by supervisors; for the design of Teacher Internship Program II is good enough. It only needs socialization and deepening of the theory.

In the way of developing of teachers' attitude, it requires intensive understanding and deepening about eight (8) education standards in order to prepare Teacher Internship Program III (teaching assistance) with soft skills and hard skills (such as communicating using English in listening, speaking, reading and writing aspects). In producing graduates who are faithful and noble, Master of Science in English, and sensitive to the demands of future changes and challenges and have a high ability of adaptability to his era.

Based on the results of the second-year research on internships program II, it provides recommendations so students still have to improve their pedagogic, professional, and social and personality competencies and needs to continue with mastery of competencies an internships program II fields of school management. The results of the second-year research are internships program II models, internships program II guide that tailored to the study program (English Language Education) and internships program II Textbook.

\section{References}

[1] R. Bennett, “Employers' Demands for Personal Transferable Skills in Graduates: a content analysis of 1000 job advertisements and an associated empirical study," J. Vocat. Educ. Train., vol. 54, no. 4, pp. 457-476, Dec. 2002.

[2] T. Airaksinen, "The Philosophy of Professional Ethics," Encyclopedia of Life Support Systems. p. 6. 
[3] N. S. Sukmadinata, Metode Penelitian Pendidikan. Bandung: Remaja Rosdakarya, 2012.

[4] Furqon and E. Emilia, Penelitian kuantitatif dan kualitatif: Beberapa isu kritis. Bandung: Rizqi Press, 2010.

[5] NIAD-UE and Badan Akreditasi Nasional Perguruan Tinggi, "Briefing on Indonesia: Quality Assurance in Higher Educaion." 2014. 